\title{
Metode Mengajarkan Kekudusan Hidup pada Anak-anak ditinjau dari 1 Petrus 1:16
}

\author{
Djoko Sukono', Eko Wahyu Suryaningsih ${ }^{2}$ \\ 1,2Sekolah Tinggi Teologi Baptis Indonesia, Semarang \\ 1djokosukono@stbi.ac.id, 2ekowahyu@stbi.ac.id
}

\begin{abstract}
Holiness is one of God's essential attributes of His Divinity. The Bible clearly shows this nature of God, that He is a holy God. In 1 Peter 1:16 the human being who is in Him is also expected to live a holy life. Holiness itself is obtained through the Spirit of God who cleanses the human soul from sin, is renewed into the likeness of Christ, and by receiving grace to obey God according to His Word. The Bible guides Christians to live holy lives, both before God and before their fellow human beings. The importance of maintaining the holiness of life so that it is necessary to teach children from an early age. The topic of this research is how the method of teaching holiness to children is seen from 1 Peter 1:26. This article was written using the study of biblical theology to understand the holiness of God and a descriptive qualitative research approach and got the results that the holiness of life is a gift from God in Christ and must be taught to children about the holiness of life through the example of life by the parents around them.
\end{abstract}

Keywords: 1 Peter 1; holiness; teaching children; teaching methods

\begin{abstract}
Abstrak: Kekudusan merupakan salah satu sifat Allah yang esensial dari Keilahian-Nya. Secara jelas Alkitab menunjukkan sifat Allah ini, bahwa Ia adalah Allah yang kudus. Dalam 1 Petrus 1:16 manusia yang ada didalam Dia juga diharapkan untuk hidup Kudus. Kekudusan sendiri diperoleh melalui Roh Allah yang menyucikan jiwa manusia dari dosa, diperbarui menjadi serupa dengan Kristus, dan dengan menerima kasih karunia untuk menaati Allah sesuai dengan FirmanNya. Alkitab menuntun orang Kristen untuk hidup kudus, baik di hadapan Allah maupun dihadapan sesama manusia. Pentingnya menjaga kekudusan hidup sehingga perlunya mengajarkan sejak dini kepada anak-anak. Yang menjadi topik penelitian ini adalah bagaimana metode mengajarkan kekudusan kepada anak-anak di-tinjau dari 1 Petus 1:26. Artikel ini ditulis mengunakan kajian teologi biblika untuk memahami kekudusan Allah dan pendekatan penelitian kualitatif deskriftif dan mendapatkan hasil bahwa kekudusan Hidup adalah anugerah Allah didalam Kristus dan harus diajarkan kepada anakanak tentang kekudusan Hidup melalui teladan hidup oleh orang tua di sekitarnya.
\end{abstract}

Kata Kunci: 1 Petrus 1; kekudusan; mengajar anak-anak; metode mengajar

\section{PENDAHULUAN}

Karya Penebusan Kristus di atas kayu salib adalah untuk menyelamatkan seluruh umat manusia dari dosa. Setiap orang yang percaya kepadaNya akan mendapatkan keselamatan tersebut. Karena manusia telah diselamatkan, sehinga sekarang telah menjadi kepunyaan Allah. Setiap orang yang percaya telah diangkat dari jurang dosa dan dikuduskan itu sebabnya perlu menjaga diri untuk tetapdalam kekudusan. Oleh karena Allah sifatnya kudus, bagiamana manusia harus menjaga 
diri untuk tetap kudus. Memberikan pengajaran kepada semua orang percaya tentang menjaga kekudusan diri tidaklah mudah, apalagi mengajarkan kepada anakanak dari sejak dini tentang kekudusan hidup adalah hal yang sulit.

Kekudusan diperoleh melalui Roh Allah yang menyucikan jiwa manusia dari dosa, diperbarui menjadi serupa dengan Kristus, dan dengan menerima kasih karunia untuk menaati Allah sesuai dengan Firman-Nya. Alkitab menuntun orangKristen untuk hidup kudus, baik dihadapan Allah maupun dihadapan sesama manusia. Mengapa manusia harus hidup kudus? Karena Allah itu sendiri Kudus adanya. Pertanyaannya sekarang adalah, bagaimana manusia bisa hidup mengarah kepada kekudusan itu? Sebab, kehidupan di dunia ini banyak sekali godaan yang seringkali mengganggu manusia dalam menjaga kehidupan kudus kita. Itu sebabnya penting mengajarkan sejak dini kepada anak-anak untuk dapat menjaga kekudusan diri. Kebenaran ini adalah kebenaran yang hakiki dan pengajaran sepanjang masa, tetapi bagaimana kita dapat memberikan pengajaran tentang menjaga kekudusan diri ini khususnya anak-anak usia balita.

\section{METODE PENELITIAN}

Artikel ilmiah ini merupakan jenis penelitian kualitatif dengan mengunakan pendekatan studi biblika. Untuk menyajikan konsep tentang Allah yang kudus peneliti melakukan kajian dalam 1 Petrus 1:16, dan melakukan analisis mendalam (eksegesis) terhadap teks tersebut. Selain itu peneliti juga melakukan studi pustaka terhadap buku-buku teologi yang memiliki keterkaitan langsung, sampai kepada melakukan sintesis terhadap topik ini. Dengan demikian, diharapkan kajian ini dapat menemukan gambaran yang komprehensif dan utuh terhadap konsep kekudusan hidup sebagaimana dimuat dalam 1 Petrus 1:16.

Dalam proses penelitian ini, peneliti berupaya untuk menyuguhkan pandangan-pandangan yang alkitabiah, dimana pada bagian ini peneliti menggali dari pandangan para teolog, dan peneliti juga mengunakan pendekatan diskusi akademik dengan rekan-rekan dosen pendidikan anak yang memiliki kualifikasi mumpuni, serta mengikuti seminar yang bersingungan langsung dengan judul ini. Dengan demikian topik ini peneliti paparkan secara deskriptif sesuai dengan hasil temuan biblis dan praktis. Pada akhirnya diharapkan agar artikel ini dapat dimplementasikan dalam konteks pendidikan khususnya pendidikan Agama Kristen bagi anak, tentang kekudusan hidup.

\section{PEMBAHASAN}

\section{Kajian Teoritis Tentang Kekudusan \\ Pengertian Kekudusan}

Kata Kudus bila di artikan secara harafiah dapat diterjemahkan menjadi kata "memotong" atau "memisahkan". Istilah lain dari Kudus itu adalah "dibenarkan", "disucikan" atau "disepesialkan/dikhususkan". Dalam Perjanjian Lama, kata dasar kudus itu dibaca Qadosy atau Qodesy, yang berarti suci atau murni. Sedangkan di dalam Perjanjian Baru dipakai kata hagios, yang sebenarnya juga memiliki arti suci. Kata hagios lebih mempunyai dasar pemikiran mengenai keterpisahan dan kesucian 
terhadap Allah.Louis Berkhof, seorang ahli teologi dalam bukunya yang berjudul Systematic Theology, mengatakan bahwa "Kekudusan ialah sesuatu yang sesuai atau sejalan dengan segalasesuatu yang dapat dibayangkan mengenai Allah". Berikut adalah limahal yang perlu kita perhatikan dalam menjaga kekudusan diri

\section{Pertama, Kekudusan Menuntut Pemisahan dari yang Duniawi ke yang Rohani}

Kekudusan mengandung pengertian terpisah dari cara-cara fasik dunia dan dipisahkan untuk mengasihi, melayani, dan menyembah Allah. (Im. 11:44). Kekudusan adalah sasarandan maksud pemilihan manusia di dalam Kristus (Ef 1:4). Itu berarti menjadi serupa dengan Allah dan mengabdi kepada-Nya sementera hidup untuk menyenangkan-Nya (Rm. 12:1; Ef. 1:4; 2:10; 1Yoh. 3:2-3). Allah itu kudus, dan apa yang berlaku bagi Allah juga harus berlaku bagi umatNya. Karena Allah bersifat kudus, maka sudah selayaknya sebagai umat kepunyaan Allah juga harus hidup kudus. Allah telah memberikan kuasa (eksousia) kepada manusia untuk menjadikan suci. ${ }^{1}$ Dengan menggunakan eksusia tersebut, manusia sebagai umat kepunyaan Allah dimungkinkan untuk memiliki kesucian seperti Allah sendiri. Asalkan mengerti makna dari pengorbanan Tuhan atas hidup dan memiliki komitmen yang besar untuk menjaga hidup agar tetap kudus maka hal itu tidak mustahil. Seperti yang tertulis di Kitab Markus 9:23, Jawab Tuhan Yesus, "Katamu: jika Engkau dapat? Tidak ada yang mustahil bagi orang yang percaya!".

Dunia ini mempunyai standard tersendiri tentang apa itu kekudusan. Allah itu kudus, Ia tidak menuntut manusia untuk menjadi maha Kudus, maha kuasa seperti Allah, namun ada satu hal yang penting di sini, Ia mengajak manusia untuk mengambil bagian di dalam kekudusanNya, sehinggadapat menjadi sama seperti diriNya (Ibr. 12:10). Hidup yang tidak kudus bagi masyarakatsekitar dianggap tabu, apalagi bagi orang percaya. Sebagai orang percaya seringkali menjadi sorotan terhadap lingkungan sekitar. Tingkah laku secara tidak sadar menjadi perhatian orang lain. Misalkan saja seorang anak perempuan yangsering terlihat pulang larut malam dan dipergoki oleh tetangganya dalam keadaan mabuk dengan menggunakan pakaian sexy, orang akan menyebutnya tidak kudus. Sebaliknya, sepasang suami-isteri mengalami trauma dalam hidup pernikahnannya, lalu mereka memutuskan untuk berpisah, apakah iniberarti kudus? Tentu tidak, sebab standard suami-isteri yaitu mereka harus berdua dan tidak boleh berpisah, seperti firman Tuhan katakan "apa yang sudah dipersatukan "Tuhan itu kudus adanya". Pemisahan dari duniawi ke rohani pasti melibatkan Tuhan. Banyak orang di dunia inimemisahkan diri dengan cara hidup mereka sendiri, menjauhi larangan-laranganNya, tidak makan daging, menderita demi 'tuhannya". Namun, orang percaya dipanggil untuk meninggalkan ketidakkudusan tetapi menerima dan mengejar kebenaran Allah.

Di era globalisasi ini, semua informasi ini dapat dengan mudah didapatkan pada detik ini juga. Segala penjuru dunia dapat terkoneksi dengan mudahnya dengan kekuatan internet. Dengan adanya globalisasi ini tentu ada dampak positif

1 Stevanus Kalis, Transformasi Hidup Seperti Yesus: Jalan Hidup Menuju Kesempurnaan (Yogyakarta: Lumela, 2018), 21 
dan negatifnya.Dampak positifnya seperti yang sayakatakan tadi, seluruh dunia dapat terkoneksi, kita dengan mudah mendapatkan berbagai infomasi pada detik ini juga.Namun di balik dampak positif itu, terdapat dampak negarif yang sedang mengintai.Contoh kita mengetahui mode atau tren fashion yang sedang digandrungi oleh anak muda jaman sekarang.Kita harus pandai mengendalikan diri kita untuk pintar dalam memilih mode pakaian yang tetap menjaga kekudusan kita, jangan semua mode pakaian kita ikuti dan tiru.

Seringkali ditemukan bahwa anak-anak gadis zaman sekarang, bahkan yang mengaku anak TUHAN dengan berani memakai model pakaian "you can see". Inikah yang disebut abad modern atau era globalisasi? Kalau kita mengaku kita sebagai orang percaya yang mau hidup kudus, kita harus terpisah dari kehidupan modern seperti ini. Mungkin kita tidak merasakan apa-apa, namun kehadiran kita sebagai orang percaya dengan model seperti itu telah menggoda orang-orang di sekitar kita jatuh ke dalam dosa. Apalagi bagi seorang pria, melihat semacam itu tentu ada peperangan tersendiri di dalam hati dan pikirannya, karena kelemahan pria ada di matanya.Oleh karena itu, kita sebagai umat kepunyaan Allah harus bisa memilahmilah hal-hal duniawi seperti itu untuk menjaga kekudusan diri kita.Jadi, "menjadi kudus" menunjuk kepada karakter Allah (majesty and the glory of God). ${ }^{2}$

Keterpisahan dari dunia, juga berarti keterpisahan dari doa dan dikuduskan dalam kemurnian dan dipersembahkan secara khusus bagi Tuhan Allah. Kondisi ini mengandung arti suatu keadaan di mana Allah melalui kasih karunia-Nya memisahkan orang-orang berdosa dan memperbaharui hidupnya sesuai dengan gambar dan rupa Allah. Dengan demikian makin tercipta suatu pertumbuhan rohani semakin matang dan secara progresif melalui iman kepercayaan kepada Yesus Kristus. Kedua, kekudusan menuntut standard hidup yang sesuai dengan kemauan Allah. Kekudusan yang dituntut Allah terhadap diri kita bukan sekadar pemindahan dari posisi duniawi ke rohani; namun lebih dari itu harus secara alkitabiah yakni standard kekudusannya bukan melalui penglihatan manusia saja, namun itu semata-mata tuntutan Tuhan. Bayangkan saja apabila standard kekudusan itu berdasarkan pemikiranmanusia, maka akan timbul penilaian yang tidak objektif.

Ada orang Kristen "rohani" yang mengatakan bahwa orang percaya itu tidak boleh membaca majalah, lalu tidak boleh menonton televisi, bahkan menganjurkan anggota gereja menjual televisinya lalu uangnya dipersembahkan untuk pekerjaan Tuhan. Siapakah yang boleh menetapkan standard ini? Apakah manusia yang kita sebut "rohani" itu? Jika benar majalah itu tidak boleh dibaca, maka harus kita lihat terlebih dahulu majalah apakah itu? Film apakah itu yang ditonton di televisi? Kalau majalah atau film yang tidak senonoh tentu kita semua menyetujuinya, namun bukankah melalui majalah, melalui televisi, kita dapat menerima berita-berita tentang perkembangan dunia dan sebagainya. Cukup membingungkan, karena standardnya tidak kuat, oleh sebab itu sekali lagimemerlukan firman Tuhan sebagai standard. Selain itu, sering kali kita juga menjumpai orang-orang yang mengaku

\footnotetext{
${ }^{2}$ Herman Yermia, Hidup Dalam Kekudusan, 30
} 
diperintah oleh Allah berdasarkan emosi atau pikiran mereka sendiri, lalu mereka mulai menegor sana-sini. Bila bukan Alkitab sebagai patokan standar, akan muncul penyesat-penyesat di dunia, walaupun secara ekstrim etika mereka mengajarkan yang baik.

Alkitab mengatakan di dalam Matius 5:48 "Karena itu haruslah kamu sempurna, sama seperti Bapamu yang di sorga adalah sempurna." Selain itu di dalam 1 Tesalonika 4:7 tertulis "Allah memanggil kita bukan untuk melakukan apa yang cemar, melainkan apa yang kudus. Inilah alasan mengapa kita itu harus hidup kudus. Persoalan di sini bukan hanya dipanggil, namun juga dipilih, bahkan dikhususkan, disucikan, dan dipisahkan untuk menjadi suatu umat yang kudus bagiAllah (lih. Kel. 19:6; Im. 20:26; 1Pet. 2:9).

Oleh karenanya, agar kita mengetahui "standar" dan maksud Bapa atas diri kita; kita harus hidup kudus, kita harus selalu melibatkan Allah dalam setiap hal yang kita lakukan. Karena Allah yang telah memilih kita, kita telah menjadi milik kepunyaanNya, maka kita wajib selalu melibatkanNya dalam hal apapun. Kita bersandar sepenuhnya kepada Allah, karena dengan Allah kita dimampukan untuk melakukan segala sesuatu. Dan terlebih lagi agar kita dimampukan menjaga perilaku kita, menjaga pikiran, perkataan kita. Kita tahu bahwa pikiran dapat menentukan kata-kata dan tindakan kita. Jika pikiran kita baik, niscaya kata-kata dan perbuatan kitapun juga baik. ${ }^{3}$

\section{Ketiga: Kekudusan dari Tuhan Bermutu Tinggi}

Apabila meletakkan berbagai peraturan-peraturan sendiri, tanpa berdasarkan firman Tuhan, namun berdasarkan kemauan manusia saja, maka kita akan merasa sangatsengsara sekali. Misalnya tentang jangan sentuh ini dan itu, jangan makan ini dan itu, jangan memakai ini dan itu, semua itu merupakan peraturan yang dibuat manusia, namun seakan-akan tidak berguna karena tidak menyelamatkan kita. Peraturan-peraturan itu ada karena pemikiran manusia yang terlahir dari normanorma sosial yang berlaku di masyarakat. Peraturan-peraturan yang menilai bahwa setiap orang yang hidup di lingkungan yang menerapkan peraturan tersebut haruslah mengikutinya. Bila tidak mengikutinya maka akan dicap orang yang tidak baik.

Pada zaman sekarang ini mungkin seringkali kita melihat atau menemukan bahwa orang-orang gampang sekali untuk menghakimi perilaku seseorang yang ia lihat karena merasa dirinya lebih baik daripada orang yang ia hakimi tersebut. Harus kita sadari bahwa batasan penentuan seseorang itu Kudus atau tidak ditentukan oleh Tuhan, manusia tidak mempunyai kredibilitas untuk memberikan penilaian, yang berhak danyang dapat menilai adalah Tuhan. "Bukan yang dilihat manusia yang dilihat Allah; manusiamelihat apa yang di depan mata, tetapi Tuhan melihat hati." (1Sam. 16:7). Kesanggupan manusia hanya melihat dari luar saja, padahal yang di luar itu banyak tipuannya, namun Tuhan kita melihat luar dalam, sehingga

\footnotetext{
${ }^{3}$ Stevanus Kalis, Transformasi Hidup Seperti Yesus (Jalan Hidup Menuju Kesempurnaan), Yogyakarta: Lumela, 2018, hlm 21
} 
kepada Tuhan kita tidak bisa menutup diri. Oleh sebab itu, waspadalah, Tuhan senantiasa bersama kita, hiduplah kudus sesuai firman-Nya.

Keempat: Kekudusan yang Tampak di Luar Saja Bukan Kekudusan yang Sesungguhnya

Kekudusan itu bukan hanya terletak pada perlakukaan yang terlihat Kudus, namunlebih dari itu juga menyangkut hati yang Kudus atau transparan, tidak ada yang boleh tersembunyi. Karena kekudusan itu sendiri dapat dipalsukan orang. Tuhan Yesus mengatakan orang Farisi itu seperti kubur, yang diluar nampaknya putih bersih, namun sesungguhnya di dalamnya mengandung bangkai. (Mat. 23:27). Hidup kudus merupakan harapan Tuhan Yesus juga. Hidup kudus haruslah menjadi gaya hidup orang Kristen yang sudah mengalami perjumpaan pribadi dengan Allah. Dengan telah mengalami perjumpaan pribadi, dirinya pastilah mengerti akan makna pengorbanan Kristus. Apabila kita tidak hidup kudus, maka sama saja kita telah menghina dan menyangkali karya Kristus di atas kayu salib.

Beda dengan orang-orang yang mengaku Kristen tetapi hanya sebagai status saja, belum mengalami perjumpaan pribadi dengan Kristus. Dirinya rajin berdoa, rajin beribadah ke gereja, rajin memberikan persembahan. Namun selepas melakukan kegiatan rohani, dirinya kembali berkutat dengan kehidupan duniawinya yang dengan kata lain, kembali melakukan dosa-dosa. Tiap hari Minggu ia rajin ke gereja, namun pada hari Senin sampai dengan hari Sabtu, ia hidup secara duniawi. Apa artinya kita terlihat begitu aktif beribadah, giat melayani, rajin memberikan persembahan, namun hidupnya tidak berkenan kepada Tuhan. Tuntutan Tuhan bukan sekadar praktek agamawi, namun sekaligus adapertobatan yang sungguhsungguh. Nilai orang percaya yang demikian yang dituntut oleh Tuhan. Mari kita mengejar dan berjuang untuk mencapainya.

\section{Kelima: Roh Kudus Memampukan Seseorang untuk Hidup Kudus}

Ketika tahu bahwa tujuan penebusan Allah dalam hidup seorang yang telah ditentukan dari semula. Dan maksud dasar penentuan semula, yaitu bahwa manusia yang menerima keselamatan Allah harus mempunyai hubungan yang kudus dan hidup dengan Dia sebagai anak-anakNya, serta menjadi serupa dengan gambar dan citra Kristus. ${ }^{4}$ Memang sebagai manusia, tentu banyak memiliki kekurangan karena sifat kedagingan, berbeda dengan Allah yang sempurna dan tanpa cacat cela. Bila telah berusaha untuk hidup kudus, di tengah jalan seringkali menemukan tantangan-tantangan yang menurut ukuran manusia berat. Namun Allah tidak akan meninggalkan. Manusia dapat meminta pertolongan Roh Kudus untuk selalu menjaga, memampukan untuk melewati setiap tantangan yang dihadapi.

Roh Kudus memberikan hikmat dan pengertian tentang arti pengorbanan Kristus. Dan Roh Kudus pun menjauhkan dan memperingatkan orang percaya dari hal-hal duniawi. Dan dengan diri kita yang selalu berusaha untuk hidup sesuai dengan perintah Tuhan, maka hidup pun akan menghasilkan Buah Roh. Buah Roh menghasilkan kebaikan dan mengubahkan sifat-sifat dasar manusai. Dan seperti yang dikatakan di atas, bahwa sebagai orang percaya, tentu kehidupan menjadi sorotan banyak orang di lingkungan sekitar. Orang akan banyak menilai perilaku dan

${ }^{4}$ David D. Duncan, Hidup dalam Kristus (Malang: Gandum Mas, 1985), 124 
sifat dalam bersosialiasi di kehidupan sosial. Bila berperilaku jelek dan tidak hidup kudus, tentu orang lain akan menilai jelek, dan apabila hidup baik, berdampak bagi kehidupan sekitar yang merupakan hasil dari Buah Roh, orang lain tidak hanya menilai bahwa orang baik, tetapi lebih daripada itu, lingkungan sekitar juga akan melihat dan merasakan Kristus dalam kehidupan dan dapat bersaksi kepada orangorang tersebut. Dan nama Tuhan pun dapat dimuliakan.

\section{Metode Mengajarkan Kekudusan kepada Anak-anak}

Pendidikan Kristen adalah usaha sengaja dan sistematis, ditopang oleh upaya rohani dan manusiawi untuk mentransmisikan pengetahuan, nilai, sikap, keterampilan dan tingkah laku yang mengupayakan perubahan-perubahan informasi pribadi, kelompok, bahkan struktur oleh kuasa Roh Kudus sehingga peserta didik hidup sesuai dengan kehendak Allah sebagaimana dinyatakan Alkitab, terutama dalam Yesus Kristus. Pengertian anak menurut Kamus Besar Bahasa Indonesia offline disebutkan bahwa "anak artinya keturunan kedua, manusia yang masih kecil; masih kecil (belum dewasa). Dalam mengajarkan kepada anak-anak sangat dibutuhkan keteladanan, sama halnya dengan mengajarkan kekudusan maka cara terbaik untuk mengajarkan tentang kekudusan adalah dengan memberikan teladan kehidupan.

Ada banyak cara untuk dapat membantu anak-anak memahami kekudusan Tuhan, dan menjadikan sesuatu yang sangat penting dalam hidup anak-anak. Caracara yang dapat dilakukan adalah dengan membaginya dalam dua area khusus yaitu didalam kelas, dan dalam keluarga. Didalam kelas hal yang harus dilakukan adalah dengan memprioritaskan waktu yang digunakan untuk benar-benar mengajarkan Firman Allah tentang Kekudusan, memilih lagu-lagu dan himne yang mendorong anak-anak untuk sungguh-sungguh menikmati kebaikan Allah, mengajarkan tentang perlunya kekudusan hidup dalam setiap hidup anak-anak. Pengajaran kepada anakanak tentang kekudusan hidup adalah hal yang penting untuk pertumbuhan iman anak-anak. Manusia dapat percaya dan bergantung pada Tuhan karena Dia Kudus. Ketika anak-anak belajar bahwa Tuhan itu kudus, itu menciptakan fondasi kepercayaan seumur hidup kepada Tuhan. Anak-anak diajarkan untuk memahami Tuhan dengan benar untuk menjadi kudus karena Dia Kudus.

Tuhan adalah lebih besar dari siapapun dan apapun didunia ini, Tuhan itu sempurna segala sesuatu tentang Tuhan adalah sempurna dan tidak ada keburukan di dalamnya sama sekali. Karena Tuhan adalah Kudus dalam kasih dan keadilanNya, itu berarti kita dapat mempercayai-Nya sepenuhnya. Inilah cara Tuhan membuat kita juga dapat memiliki kekudusan hidup. Untuk dapat mengajarkan tentang kekudusan hidup ini hal yang dilakukan adalah dengan memulai mengajarkan Alkitab. Karena anak-anak belajar melalui gambar kata dan contoh maka cerita Alkitab akan menunjukkan kepada mereka bagaimana Tuhan menyatakan diri-Nya adalah Kudus. Mengajarkan tentang kematiannya diatas kayu salib itu adalah bentuk pemberian diri Kristus dan adalah merupakan kebalikan dari sifat keegoisan, itulah ke- 
kudusan. Berbicara tentang kemurahan hati dan pengampunan Tuhan Yesus kepada Zakheus itulah kekudusan.

Yang kedua, pengajaran yang penting adalah dalam keluarga dengan menunjukkan kepada anak-anak tentang kehidupan sehari-hari. Anak-anak belajar melalui dunia bermain, dan mereka sering bermain dalam imajinasi mereka apa yang telah mereka lihat dalam kehidupan nyata. Anak-anak akan mengerti seperti apa kekudusan itu ketika orang tua dan orang dewasa disekitar mereka memberikan diri dan teladan hidup bagaimana bersikap bijaksana. Ceritakan juga bagaimana orang tua harus belajar menjaga kekudusan dan tantangan apa yang dihadapi untuk bisa hidup kudus. Memberikan keyakinan kepada anak-anak bahwa untuk menjadi kudus bukan karena usaha manusia tetapi diterima dari Allah. Merikan Ayat-ayat yang menolong mereka memahami secara khusus tentang kekudusan Allah yang diberikan kepada manusia seperti dalam Perjanjian Lama Imamat 19:2 dan dalam Perjanjian Baru 1 Petrus 1:16, jadilah kudus karena Aku kudus. Dasar paling penting dalam mendidik anak adalah dalam keluarga yang berpusat pada Allah.

\section{KESIMPULAN}

Kekudusan bisa menjadi kata yang khusus dan sulit dipahami, tetapi anakanak harus memiliki pemahaman dasar tentang konsepnya. Intinya adalah bahwa seorang Kristen dapat memiliki kekudusan karena hubungan mereka dengan Allah melalui TuhanYesus. Allah itu kudus oleh karena itu para pengikut-Nya harus kudus. Kekudusan berarti dipisahkan, itu menjadi cerminan dari kebaikan dan kebenaran Tuhan. Karya pengorbanan Kristus di atas kayu salib adalah untuk menyelamatkan seluruh umat manusia dari dosa. Orang-orang yang percaya yang sudah diselamatkan olehNya haruslah hidup kudus, menjaga kekudusan dirinya, karena Allah pun bersifat kudus seperti ungkapan 1 Petrus 1:16. Manusia dengan segala kekurangannya mungkin merasa berat, namun asalkan mengerti makna dari pengorbanan Kristus dan juga memiliki komitmen yang besar, tidak ada yang mustahil karena Allah pun tidak akan meninggalkan diri kita dalam keadaan apapun. Kekudusan hidup bukan pilihan bagi orang Kristen. Hidup kudus adalah cara hidup orang Kristen yang telah mengalami anugerah penebusan Kristus. Itu sebabnya penting mengajarkan kekudusan hidup kepada anak-anak dengan dua cara, yaitu dari dalam kelas dan dari keluarga. Ddari dalam kelas dengan memberikan pengajaran-pengajaran di sekolah maupun Sekolah Minggu dengan mengajarkan Alkitab yang bersentral pada pendidikan untuk anak; dan yang kedua melalui keluarga adalah dengan memberikan teladan langsung dari orang dewasa di sekitarnya.

\section{REFERENSI}

Stevanus Kalis, Transformasi Hidup Seperti Yesus (Jalan Hidup Menuju

Kesempurnaan), Yogyakarta: Lumela, 2018

Herman Yermia, Hidup Dalam Kekudusan

David D. Duncan, Hidup dalam Kristus, Malang: Gandum Mas, 1985

Haystead, Wes. Mengenalkan Allah Kepada Anak, Yogyakarta: Yayasan Gloria, 1998

Huraerah, Abu., Kekerasan Terhadap Anak, Bandung: Penerbit Nuansa, 2006. 